\title{
TRACES AND BURROWING BEHAVIORS OF THE CICADA NYMPH CICADETTA CALLIOPE: NEOICHNOLOGY AND PALEOECOLOGICAL SIGNIFICANCE OF EXTANT SOIL-DWELLING INSECTS
}

\author{
JON J. SMITH ${ }^{1 *}$ and STEPHEN T. HASIOTIS ${ }^{1,2}$ \\ ${ }^{1}$ Kansas Geological Survey, 1930 Constant Ave., Lawrence, Kansas 66047-3726, USA; ${ }^{2}$ Natural History Museum and Biodiversity Research Center, \\ Lawrence, Kansas 66045-7613, USA \\ e-mail: jjsmith@ku.edu
}

\begin{abstract}
This study documents the traces and burrowing behaviors of nymphs of the prairie cicada Cicadetta calliope (Hemiptera: Cicadidae), as observed in neoichnological experiments. Cicada nymphs were collected from the $\mathbf{C}$ horizons of sandy Fluvents along the Kansas River east of Lawrence, Kansas. The nymphs appeared to be fifth instars, 13-17 mm long and 6-7 mm wide. Nymphs were placed in plastic enclosures containing layers of colored, moist, very fine-grained sand. They burrowed immediately, excavating air-filled, sediment-enclosed cells between $20 \mathrm{~mm}$ and $40 \mathrm{~mm}$ long and averaging $9 \mathrm{~mm}$ wide. Burrowing was completed in three stages: (1) sediment in the forward portion of the cell was excavated and rolled into a ball with the forelimbs; (2) the nymph turned $180^{\circ}$ using a forward roll, and moved to the back of the cell; and (3) the sediment ball was pushed up against the back wall of the cell and kneaded with the forelimbs into a thin layer. Resulting burrow traces are sinuous and distinctly meniscate and demonstrate that insect larvae construct meniscate, backfilled burrows in well-drained terrestrial settings. Cicadetta calliope nymphs and their traces are excellent analogs for meniscate trace fossils commonly found in late Paleozoic-Cenozoic alluvial deposits and paleosols. Such meniscate trace fossils are useful for interpreting the paleoenvironment and paleohydrogeology of the units in which they are found. In addition, such backfilled burrows can be used to supplement the fossil record of cicada-like hemipterans, currently known only from the latest Permian to the Early Triassic.
\end{abstract}

\section{INTRODUCTION}

Neoichnologic studies are critical for the accurate interpretation of the paleoichnologic record and for comprehension of the paleoenvironmental, paleohydrologic, and paleoecologic information provided by trace fossils. Most previous neoichnologic studies, however, have been conducted in the marine realm-using marine arthropods, bivalves, and echinoderms to examine the range of organism behaviors and traces produced under different depositional conditions (e.g., Frey, 1968, 1970; Bromley and Asgaard, 1975; Ekdale and Berger, 1978; Frey et al., 1984; Pemberton and Frey, 1985; Atkinson and Taylor, 1991; Kanazawa, 1992; Gingras et al., 2002, 2004). The experimental results of these investigations have been used to interpret the ecological, biological, and environmental significance of marine trace fossils (e.g., Frey et al., 1978; Seilacher, 1978; Pemberton et al., 1992; Savrda, 1995; Bromley, 1996).

Trace fossils attributed to insects and other soil-dwelling arthropods are extremely common in continental deposits (e.g., Bown, 1982; Bown and Kraus, 1983; Genise and Bown, 1994; Thackray, 1994; Buatois et al., 1998; O'Geen and Busacca, 2001; Hasiotis, 2002, 2004; also see references in Hasiotis, 2004). Few neoichnological studies, however, have

* Corresponding author.

Copyright $($ 2008, SEPM (Society for Sedimentary Geology) documented the burrowing traces of extant temporary and permanent soildwelling arthropods (e.g., Clark and Ratcliffe, 1989; Hasiotis and Mitchell, 1993; Tschinkel, 2003), despite their role as primary agents of pedoturbation and great abundances in modern soils (Wallwork, 1970; Hole, 1981; Hasiotis, 2002).

It has been hypothesized (Hasiotis and Bown, 1992; Hasiotis and Dubiel, 1994; Hasiotis and Demko, 1996; Hasiotis, 2004) that soil-dwelling hemipterans should produce meniscate, backfilled burrows similar to some fossil burrows in Mesozoic paleosols. This suggestion is based on research by Willis and Roth (1962), who examined the behavioral responses of extant burrowing insects (Hemiptera: Cydnidae) in sedimentfilled, experimental enclosures. When the enclosures were opened, the burrowers were found in sediment-enclosed, air-filled cells that were not associated with open tunnels connecting them to the sediment surface; the exact burrowing mechanism and resultant structures were not reported by Willis and Roth (1962). Hasiotis and colleagues suggested that the cydnids backfilled their burrows as they moved through the sediment, but this hypothesis has not previously been tested experimentally.

Cicada nymphs were chosen as experimental organisms because they are abundant and widely distributed hemipterans that spend the majority their life cycle $(\sim 2-17$ years) underground as nymphal instars (Lloyd and Dybas, 1966; Dietrich, 2003). The burrowing behaviors of extant cicada nymphs have rarely been the focus of study, despite their longterm residency within soil habitats. Beamer (1928) observed cicada nymphs in glass enclosures producing cells similar to those observed by Willis and Roth (1962) for soil bugs, but he described the nymphal burrowing mechanism and not the resultant burrow morphology. Both cydnids and cicadas are soil-dwelling hemipterans that have been observed to construct burrows in which the organism is found in a cell. Thus, cicada nymphs are appropriate organisms to test the backfilled burrow hypothesis proposed for continental deposits.

This paper documents cell construction, burrowing behaviors, and traces generated by nymphs of the prairie cicada Cicadetta calliope Walker 1850 (Hemiptera: Cicadidae) under controlled experimental conditions and demonstrates the importance of using modern analogs to understand features in the ancient ichnologic record.

\section{CICADA BIOLOGY}

The first cicada-like insect body fossils occur in the Early Permian (Shcherbakov, 1984), although the earliest fossils of true cicadas (Cicadoidea) are from Triassic strata of Russia, France, and Australia. Body fossils are also known from the Lower Cretaceous of Brazil (Lefebvre et al., 1998; Rasnitsyn and Quicke, 2002). Extant Cicadoidea are divided into two families: the Cicadidae and the Tettigarctidae (Moulds, 2005). The Tettigarctidae are confined to Australia, while the Cicadidae have a worldwide distribution (Moulds, 2003) and comprise $\sim 2000$ described and possibly as many undescribed extant species. Cicadidae species are 
especially abundant and diverse in the tropics and subtropics (Dietrich, 2003).

All cicada nymphs lead exclusively subterranean lives from the first to fifth instars, burrowing through soil and feeding on the xylem sap of plant roots (White and Strehl, 1978). The behaviors and ecology of periodical cicadas such as Magicicada spp. have been studied extensively because of their unique 13- and 17-year life cycles and their synchronized, high-density emergence over large geographical areas (e.g., Simon et al., 1981; Cox and Carlton, 1988; Williams and Simon, 1995; Whiles et al., 2001). Most cicadas, however, have annually maturing generations that spend 2-6 years underground as nymphal instars, depending on the species (Lloyd and Dybas, 1966; Dietrich, 2003).

Cicada nymphs are found in a wide range of soil types, though they appear to be limited primarily to well-drained soils and by the vegetation supported by the soil (e.g., Beamer, 1928; Strandine, 1940; Hugie and Passey, 1963; Humphreys, 1989; Whiles et al., 2001; O'Geen et al., 2002). Nymphs have been reported $<1200 \mathrm{~mm}$ below the surface (Hugie and Passey, 1963), though nymphs are most abundant within well-rooted soil A and B horizons, typically between 100 and $300 \mathrm{~mm}$ from the surface (Luken and Kalisz, 1989; O'Geen and Busacca, 2001). Burrowing depth varies depending on the species, developmental stage of the nymph, depth of root systems fed upon, and such soil characteristics as moisture content, texture, frost depth, and $\mathrm{pH}$ levels (Hugie and Passey, 1963; Luken and Kalisz, 1989). Cicada nymph soil-moisture preferences are unknown, though soil moisture was the most significant factor limiting adult cicada population size in three Illinois forests; that is, the forest with the lowest average soil moisture content (13.5\%) had nearly four times the population of the forest with the wettest $(26 \%)$ soil conditions (Strandine, 1940), suggesting that the cicada nymphs preferred betterdrained soils.

Nymphs construct open, vertical emergence burrows just below the soil surface toward the end of the fifth-instar developmental stage (e.g., Dybas and Davis, 1962). Emergence burrows range from $70 \mathrm{~mm}$ to $400 \mathrm{~mm}$ long and commonly terminate in a bulbous chamber known as a feeding cell, which is slightly larger in diameter than the burrow shaft (White et al., 1979; Humphreys, 1989; Luken and Kalisz, 1989). They occupy the feeding cell prior to final emergence (Beamer, 1928). Burrow walls are solidly compacted and lined with mud pellets in some species (Dybas and Davis, 1962; Humphreys, 1989; Luken and Kalisz, 1989). Emergence burrows are long-lived structures, lasting as open shafts for $<1$ year after construction (Dybas and Davis, 1962). Some cicada nymph species use excavated sediment to construct turrets or chimneys $<200 \mathrm{~mm}$ high (Humphreys, 1989; Luken and Kalisz, 1989). Turrets may assist in maintaining emergence burrow humidity by reducing exposure of the burrow interior to sunlight (Heath, 1968). Turret building varies between and within cicada species, though the conditions that initiate turret construction are unknown.

Fifth instars may occupy the feeding cell at the base of the emergence burrows for up to several weeks before an unknown stimulus triggers their final exit from the soil (Beamer, 1928). Emergent nymphs then climb any vertical surface to which they can attach themselves in preparation for their final molt (ecdysis) into a winged and sexually mature adult that lives for 2-6 weeks (Beamer, 1928). Females typically mate within a few days after ecdysis and immediately oviposit into soft or woody plant tissue. First instars hatch after 1-10 months (depending on the species), fall to the ground, and burrow immediately to begin the life cycle anew.

\section{MATERIALS AND METHODS}

Five cicada nymphs were collected from pits excavated in soils classified as Fluvents, which were developed on overbank splays north of the Kansas River and east of Lawrence, Kansas. The study area is located in an open area $\left(38^{\circ} 50^{\prime} \mathrm{N}, 95^{\circ} 10^{\prime} \mathrm{W}\right)$ vegetated with grass and small shrubs between an artificial levee and the river (Fig. 1).

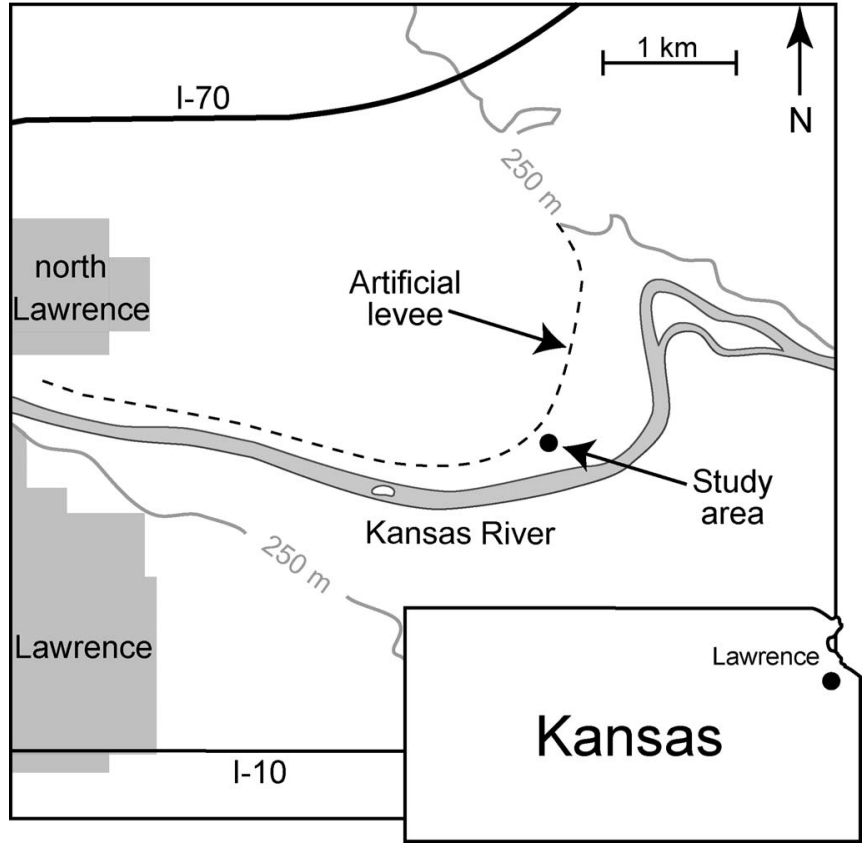

FIGURE 1-Location where cicada nymphs were collected on the Kansas River floodplain, east of Lawrence, Kansas.

Four burrowing experiments were conducted in a plastic-walled enclosure partitioned into three sections, one measuring $90 \mathrm{~mm}$ long $\times 25$ $\mathrm{mm}$ wide $\times 100 \mathrm{~mm}$ high, and the other two measuring $130 \mathrm{~mm}$ long $\times 25 \mathrm{~mm}$ wide $\times 100 \mathrm{~mm}$ high. The enclosures were filled with alternating 10-30-mm-thick layers of colored, very fine-grained sand to highlight sediment disturbance and backfill patterns created by the cicadas. The sand was moistened prior to placing the insects in the enclosures to mimic the natural $\mathrm{C}$ horizon conditions in which they were collected and to ensure that the sand would not collapse on the nymphs. The sand was moistened periodically during the experiments to prevent desiccation of the cicada nymphs. Undisturbed sand layers were photographed prior to the beginning of the experiments. Once the experiments began, the cicadas were video recorded while burrowing, and resulting biogenic sedimentary structures were photographed every few hours. Enclosures were covered with black construction paper when not observed to simulate a dark, subterranean environment. Each experiment was allowed to run until the cicadas had thoroughly bioturbated the sand layers. After the experiments were completed, nymphs were transferred to enclosures containing soil and vegetation collected from the A horizon of the study area.

\section{RESULTS}

The soil in the study area is characterized by a 150-200-mm-thick, organic-rich A horizon with dense rooting; a 150-mm-thick, clay-rich Bw horizon with fewer roots; a 50-200-mm-thick sand-rich BC horizon; and a sandy $\mathrm{C}$ horizon with a few widely spaced roots and distinct muddraped cross-beds (Fig. 2A). The base of the BC horizon is highly undulatory, though sharp, and appears to mark the depth of significant bioturbation of the $\mathrm{C}$ horizon. Live cicada nymphs (Fig. 2B) were found only in the lower $\mathrm{BC}$ and upper $\mathrm{C}$ horizons ( $300-500 \mathrm{~mm}$ deep) along with cicada molts and a few subvertical, cylindrical, sand-filled burrows likely produced by the nymphs (Fig. 2C).

The nymphs were identified as fifth instars of the prairie cicada $\mathrm{Ci}$ cadetta calliope - formerly assigned to Melampsalta (Metcalf, 1963) based on comparisons with photographs and anatomical illustrations in Beamer (1928). Cicadetta calliope is one of the most abundant annual 

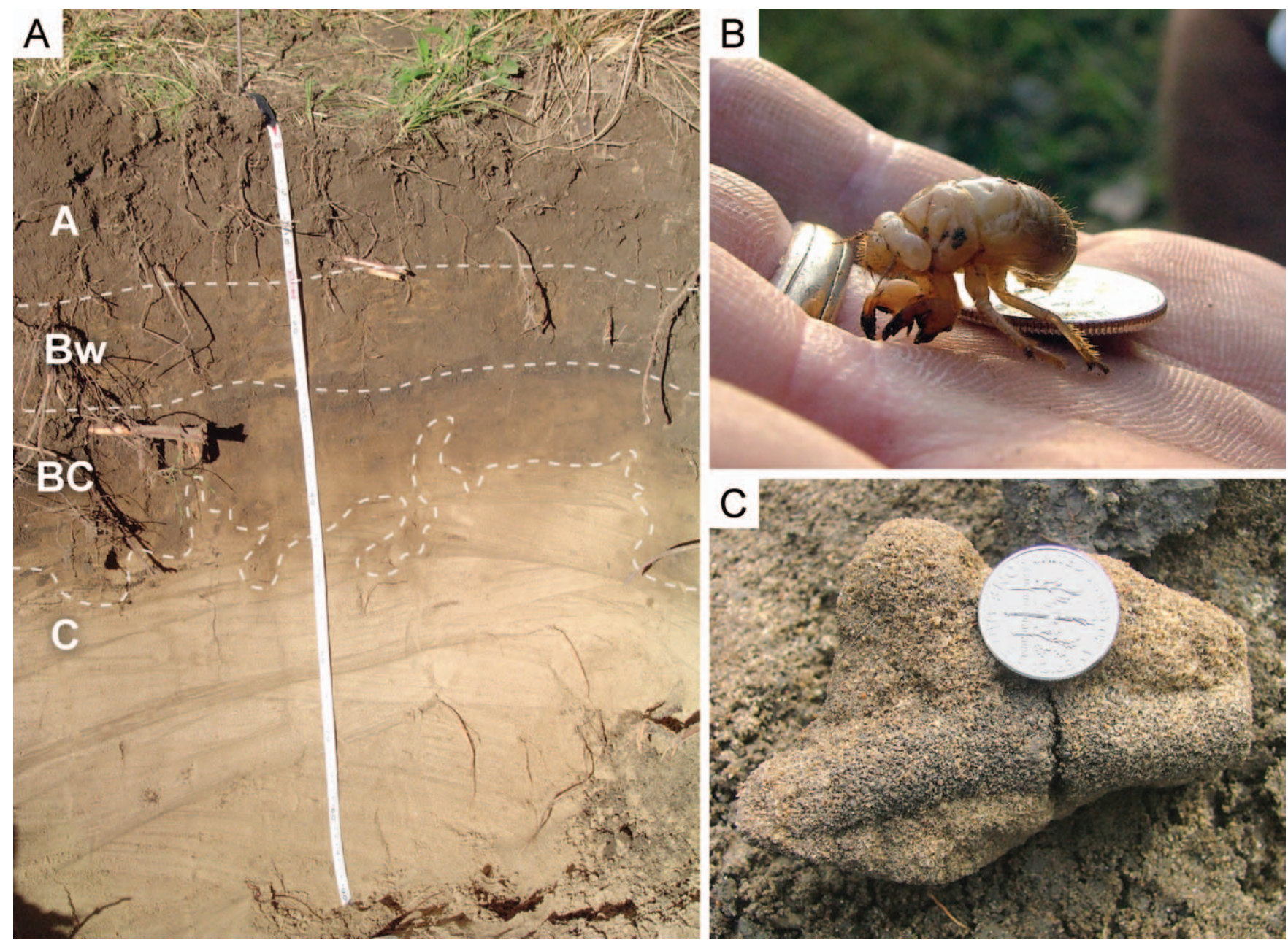

FIGURE 2-Soil excavation in study area. A) Soil horizons of Fluvents developed on overbank deposits along the Kansas River; tape $=900 \mathrm{~mm}$. B) Cicadetta calliope nymphs from the $\mathrm{BC}$ and $\mathrm{C}$ horizons in association with $(\mathrm{C})$ subvertical, sand-filled, cylindrical burrows; coins $=17.91 \mathrm{~mm}$ in diameter.

cicada species in Kansas and is common in North American prairie habitats from the Atlantic coast through the southern United States, to northern Mexico, and northwestward to Nebraska and Colorado (Davis, 1920; Smith et al., 2000). In Kansas, female $C$. calliope oviposit in June, and first instars hatch and enter the soil in August (Fig. 3). Nymphs spend approximately 4 years below the soil surface, feeding on xylem sap from the roots of grasses or woody plants. Fifth instars emerge from the soil between late May and early June, surviving for as little as 2 weeks as adults (Beamer, 1928). The five nymphs collected ranged from $13 \mathrm{~mm}$ to $17 \mathrm{~mm}$ long and from $6 \mathrm{~mm}$ to $7 \mathrm{~mm}$ wide across the thorax.

\section{Burrowing Behaviors}

Nymphs of Cicadetta calliope burrowed immediately after placement in the experimental enclosures (Figs. 4A-B). The nymphs produced a burrow with a circular-to-elliptical cross section and deposited the excavated sediment on the surface around the burrow entrance (Fig. 4C). After burrowing 10-20 $\mathrm{mm}$, the insect ceased moving sediment to the surface and instead backfilled the burrow entrance. While below the surface, nymphs occupied and maintained an elongate or ovoid air-filled cell completely enclosed by sediment. Cell dimensions measured in the multiple experiments were variable and ranged from $20 \mathrm{~mm}$ to $40 \mathrm{~mm}$ long and from $8 \mathrm{~mm}$ to $10 \mathrm{~mm}$ wide (Fig. 4D). Cicada nymphs moved through the sediment by excavating sediment from one side or wall of the cell and depositing it on the opposite cell wall (see the video in Supplementary Data ${ }^{1}$.

The nymphs excavated and manipulated sediment almost exclusively with their large sickle-shaped forelimbs (Fig. 5). The mid- and hind limbs did not come into contact with excavated sediment but instead held the nymph firmly in place while burrowing. The forelimb consists of an elongate coxa and trochanter that ends in a massive, triangular femur and a bladed tibia and tarsus. The fingerlike tibia is movable against the palm of the femur; thus, together they form a prehensile digging and grasping handlike structure. The nymphs burrowed with alternating forward thrusts of the entire foreleg into the sediment with the tibia opened (Fig. 6A). The forelimbs angled slightly inward as they thrust forward (Fig. 6B). As the forelimb retracted, the sediment was scooped by the femur toward the nymph's head and was compacted into a ball-shaped clump (Fig. 6C).

After excavation of the sediment ball, nymphs rotated $180^{\circ}$ using a forward roll while holding the sediment ball between the head and the forelegs (Figs. 6C-F). If the area of excavation was not wide enough for the forward roll, the cicadas would walk backward to a wider portion of the cell. This maneuver resulted often in the cicada facing the opposite cell wall but upside down, which it sometimes corrected. The nymphs then carried the sediment ball to the back side of the cell and pushed the sediment against the cell wall with both forelimbs (Fig. 6G). They then

\footnotetext{
${ }^{1}$ www.paleo.ku.edu/palaios
} 


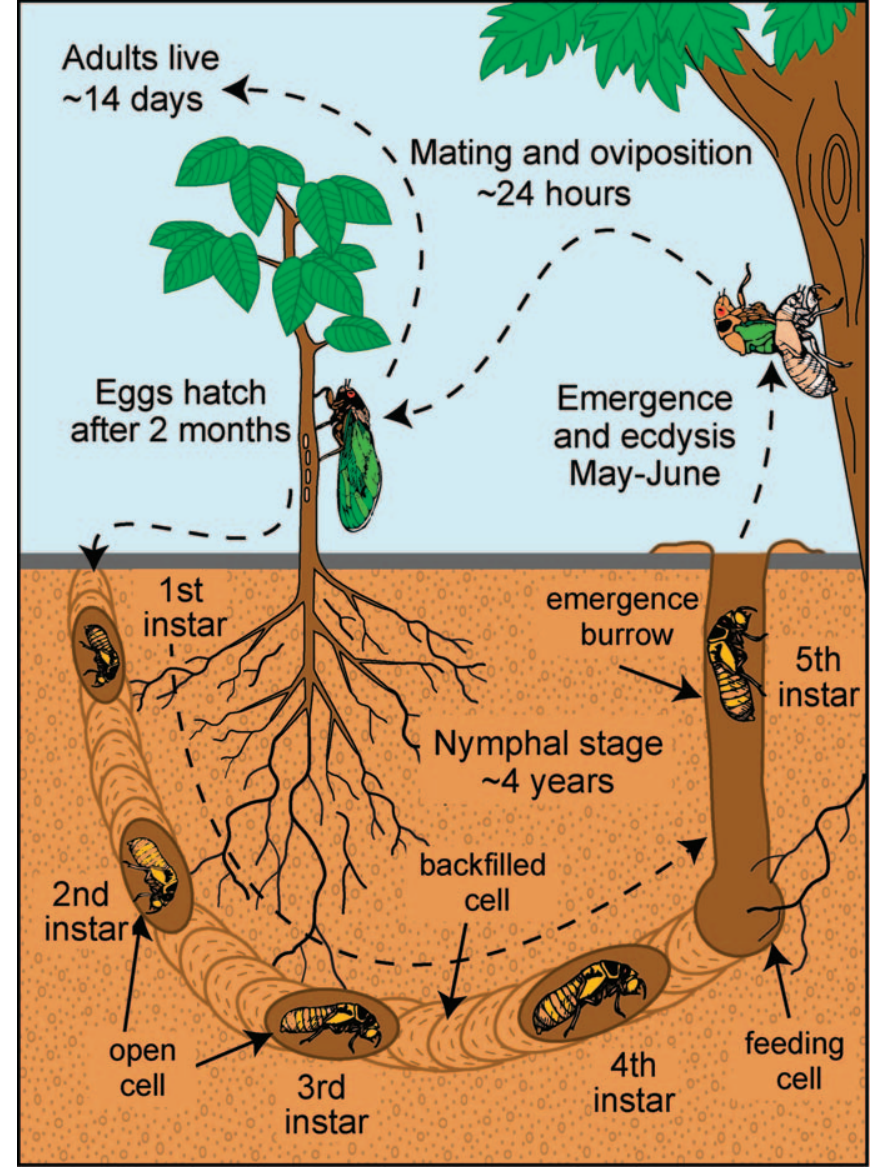

FIGURE 3-Above- and below-ground life cycle of Cicadetta calliope.

kneaded and pressed the sediment ball into a thin layer using alternating thrusts of the forelegs (Fig. 6H). After this was done, the nymphs once again made a $180^{\circ}$ forward roll and returned to the front of the cell to excavate more material. The cell and cicada, therefore, moved forward through the sediment by backfilling the cell aft.

Cicadetta calliope nymphs burrowed actively for several hours at a time, followed by longer periods of inactivity (Figs. 7A-F). Their initial behavior was to burrow $70-90 \mathrm{~mm}$ straight to the bottom of the enclosure (Fig. 7A). The nymphs burrowed in fairly random directions at depth presumably searching for food or in an attempt to burrow deeper, including a few brief returns to the sediment surface (Fig. 7E).

Only one cicada nymph transferred to the vegetated and soil-filled enclosures survived long enough $(\sim 2$ months) to produce an emergence burrow. This nymph constructed a short emergence burrow, exited the soil, and expired on the surface shortly after molting. Construction of the emergence burrow by fifth-instar nymphs is a behavior distinctly different from the burrowing and feeding behaviors of preceding instars. Sediment was excavated in the manner previously described and transported to the surface to produce a vertical, open burrow. The balls of sediment were deposited randomly around the burrow entrance and were not used in the construction of a turret or burrow lining. Beamer (1928) reports that Cicadetta calliope nymphs may occupy the emergence burrow for an extended period of time-26 days for one specimen-before emerging, though the nymph in our study exited the soil and molted immediately after completing the emergence burrow.

\section{Trace Morphologies}

The cicada nymphs burrowed below the sediment surface, producing straight to sinuous, unlined burrows filled with thin, slightly to strongly curved meniscate backfills (Figs. 7A-F). Burrow widths from all the experiments ranged from $8 \mathrm{~mm}$ to $10 \mathrm{~mm}$, only $1-2 \mathrm{~mm}$ wider than the nymph's bodies. Unevenly spaced and 10-20-mm-long sections of backfilled burrows are 13-16 mm wide, creating a tapered-and-widened appearance along the length of the burrow (Fig. 7G). Thicker burrow sections were used by the nymphs as turnaround points for backfilling purposes. The cross-sectional shape of the burrows is unknown owing to the design of the enclosures. The nymphs produced burrows with circular cross sections as they entered the sediment in each experimental run, so subterranean burrows would likely be circular to elliptical in cross section as well.

The meniscate backfills are composed of cell wall remnants made conspicuous in these experiments when sediment from different colored sand layers was incorporated into the burrow fill. The menisci vary in their curvature and distinctness along the length of the burrows. Menisci similar in appearance were typically grouped into short burrow sections or packets (Figs. 8A-B). Packets reflect separate episodes of burrowing activity based on direct observations of the cicadas during burrow excavation. Cicada burrows are, thus, composed of a series of packets containing meniscate backfill, rather than one burrow filled with a continuous series of backfills.

The one nymph that emerged produced an open, cylindrical burrow $\sim 80 \mathrm{~mm}$ long and $\sim 10 \mathrm{~mm}$ in diameter. The burrow is short compared with reported emergence burrow lengths of 70-400 mm long (White et al., 1979; Humphreys, 1989; Luken and Kalisz, 1989). The shorter emergence burrow produced in this experiment may be due to the relatively small size of the enclosure or because Cicadetta calliope is smaller (100 $\mathrm{mg}$ ) than any of the cicada species studied in the previous literature (700$2500 \mathrm{mg}$; A. Sanborn, personal communication, 2007).

\section{DISCUSSION}

\section{Preservation Potential}

Cicadetta calliope nymphs produce at least two distinct types of traces in soils during different parts of their lifecycle: backfilled burrows during the first through fifth instars and emergence burrows by older fifth instars before exiting the soil. Modern cicada nymphs are very abundant in a variety of soil types, thus increasing the preservation potential of their traces. Backfilled burrows rarely are observed in modern soils, however, because the fill material is unaltered during the burrowing process and texturally identical to the surrounding soil matrix-unless the burrowing organism incorporates sediments of different grain sizes and colors into the backfill (e.g., Hugie and Passey, 1963). Nymph burrows in soils with fluctuating water tables may be highlighted by mottles produced by preferential gleying - the redistribution of $\mathrm{Fe}$ and $\mathrm{Mn}$ in the soil profile in the presence of organic matter (e.g., Schwertmann, 1993; Vepraskas, 1999). Long-term burrowing by cicadas in clay-rich soils may promote the formation of distinct columnar, soil aggregates and nodular accumulations of calcium carbonate (Hugie and Passey, 1963).

Natural soil-forming processes can also destroy cicada nymph traces, especially in the A and upper B horizons. The impact of pedogenesis decreases with depth in the soil profile (Brady and Weil, 2002); therefore, traces produced below the most pedogenically active horizons are more likely to be preserved. Grain size of the host media will strongly influence preservation potential; burrows produced in clay-rich B soil horizons, for example, are more likely to be preserved because these are denser and harder to rework than coarser grained horizons (Brady and Weil, 2002). Nymph traces produced in highly aggradational depositional settings have the highest preservational potential because active soil-forming processes are likely to cease and move higher in the profile following major depositional events. Preservation of cicada traces is thus controlled by the intensity and duration of post-burrowing pedogenic modification and the position of the traces within the soil profile in relationship to active zones of pedogenesis.

Emergence burrows are left open following exit of the cicada nymph from the soil and therefore would have to be passively infilled with sediment to be preserved. Although sedimentation rates associated with most 

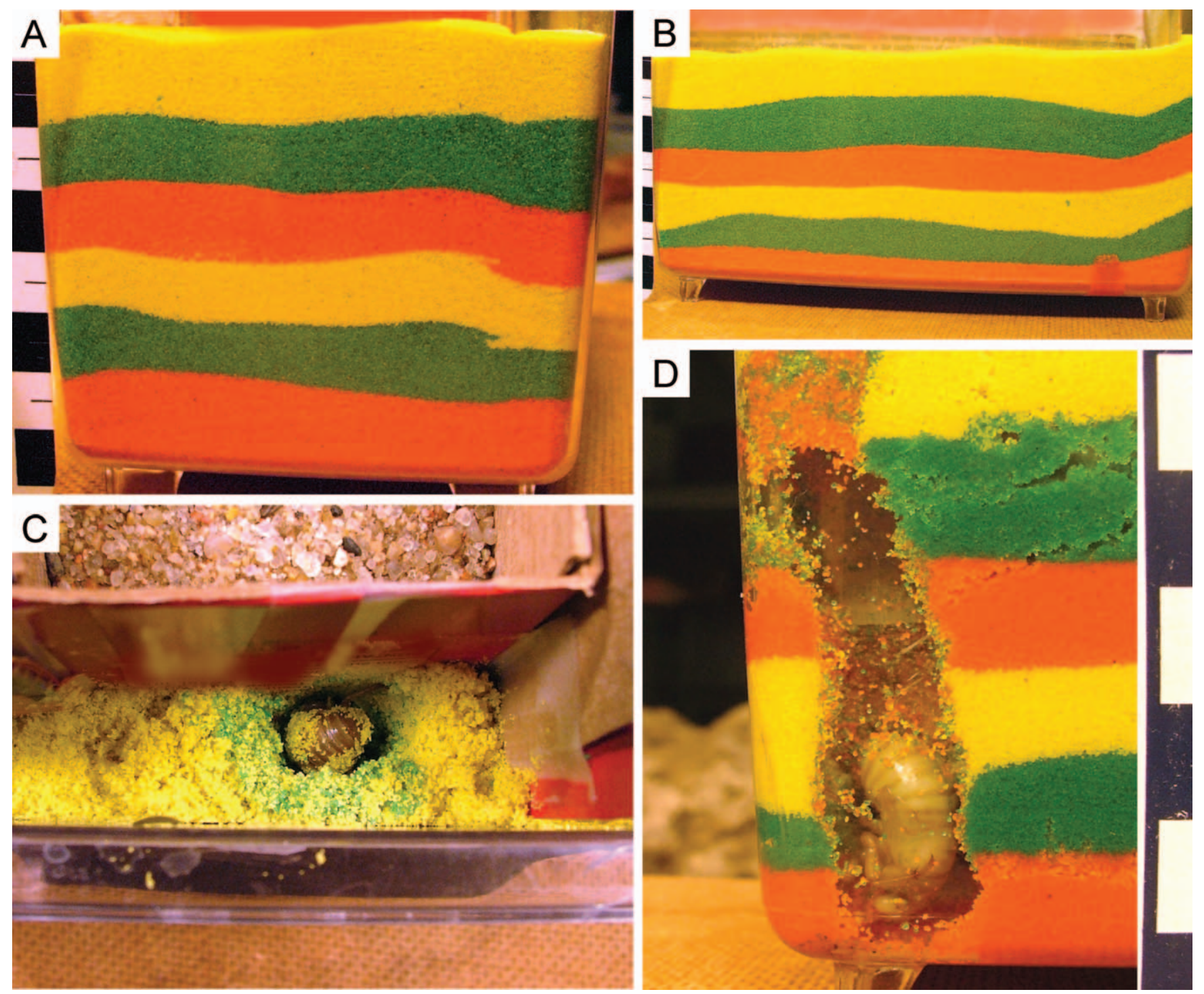

FIGURE 4-Sand-filled enclosures before (A-B) and during (C-D) cicada burrowing experiments. A) Initial layering in enclosure $90 \mathrm{~mm}$ long $\times 25 \mathrm{~mm}$ wide $\times 100$ $\mathrm{mm}$ high. B) Layering in the $130 \mathrm{~mm}$ long $\times 25 \mathrm{~mm}$ wide $\times 100 \mathrm{~mm}$ high enclosure. C) Cicada nymph burrowing after being placed into the enclosure; note the circular cross section of the burrow. D) Nymph inside a sediment-enclosed, air-filled cell.

soil environments are relatively low, emergence burrows may remain intact and open for $<1$ year after construction (Luken and Kalisz, 1989). Mud linings constructed by some cicada species may further enhance their preservation potential (Humphreys, 1989). Most emergence burrows, however, are concentrated within the A horizon and are likely to be obliterated by later bioturbation and pedogenesis unless quickly buried. The mud turrets occasionally constructed above emergence burrows are unlikely to be preserved because they quickly desiccate and weather on the soil surface (Humphreys, 1989).

\section{Paleoecological Implications}

Backfilled and vertical burrows in continental strata similar to those produced by Cicadetta calliope suggest subaerial exposure and paleopedogenic development of the host sediment. The trace makers were likely living within the vadose (unsaturated) zone of well-drained soils at the time of trace formation and their moisture tolerances may be similar in range to those measured for other soil-dwelling hemipterans (e.g., Willis and Roth, 1962). Backfilled burrows represent foraging behavior by the nymphs and are indicative of ancient soils with root systems sufficient to support a community of xylem-feeding macrofauna-whether these roots are still visible as rhizoliths or were destroyed before fossilization. The presence of such burrows indicates periods of subaerial exposure and pedogenesis in terrestrial environments and can be used to differentiate these settings from freshwater aquatic or marine paleoenvironments.

Fossil backfilled burrows in continental deposits have been interpreted generally as fodinichnia produced by deposit-feeding organisms living in subaqueous or saturated soil conditions (e.g., Toots, 1967; D'Alessandro and Bromley, 1987; Keighley and Pickerill, 1994; Buatois and Mángano, 2004; Genise et al., 2004). This interpretation is partially the result of attributing the behaviors and physiochemical requirements of backfilling marine organisms to trace fossils of continental origin and their trace makers. Meniscate burrows in continental deposits are superficially similar to such commonly occurring marine backfilled ichnofossils as Taenidium, though the differences in their detailed internal and external morphologies, genesis, and trace-making organisms make them significantly distinct (e.g., Smith et al., 2008). The interpretation of all backfilled ichnofossils as sediment-ingesting aquatic organisms would imply that their host deposits were subaqueous when the traces were made (Bromley, 


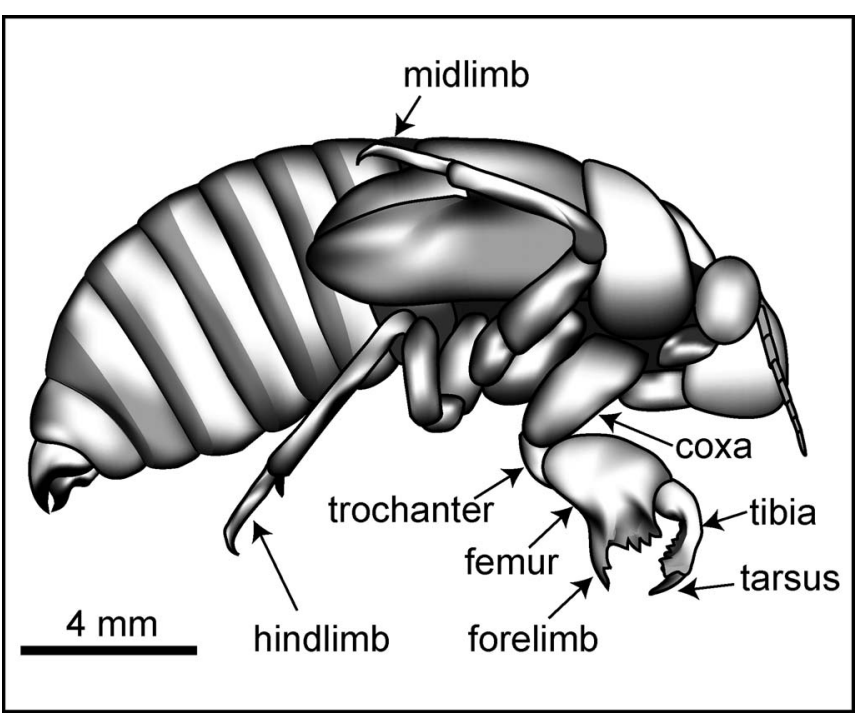

FIGURE 5-Anatomy of the fifth instar of Cicadetta calliope. Modified from Beamer (1928).

1996; Buatois and Mángano, 2004; Genise et al., 2004; Bromley et al., 2007; Buatois and Mángano, 2007). Our research demonstrates, however, that backfilling trace makers do not require water-saturated conditions and that meniscate ichnofossils in paleosols and other continental deposits most likely do not represent the work of sediment-ingesting organisms. Since the construction of backfilled burrows in freshwater subaqueous settings in the continental realm has not previously been demonstrated, earlier interpretations that meniscate burrows indicate water-saturated conditions should be revisited.

\section{Paleontological Significance}

Cicada nymph trace fossils should be common in the fossil record, given their wide geographic distribution, great abundance in modern soils, relatively high preservation potential under the right conditions (see the Cicada Biology section and Preservation Potential in the Discussion section above), and ancient fossil history. Although the earliest body fossil occurrence is often used to delineate the origin of a given taxon, ichnofossils - when diagnostic - can also be used as proxies for the occurrence of an organism or group of organisms with similar bauplans or behaviors in the fossil record (e.g., Hasiotis and Mitchell, 1993). Of equal importance, trace fossils and their host strata preserve the evolutionary history of novel behaviors and the paleoecological conditions under which these behaviors were employed. Traces produced by Cicadetta calliope in this study meet these criteria in that they are morphologically distinct and likely to be produced only by trace makers with similar anatomies and behaviors.

Backfilled burrows with morphologies similar to modern cicada nymph traces are commonly reported from paleosols and alluvial deposits in continental strata (e.g., Bown and Kraus, 1983; Hasiotis and Dubiel, 1994; Hasiotis and Demko, 1996; Savrda et al., 2000; Hasiotis, 2002; Counts and Hasiotis, 2007; Smith et al., 2008). Backfilled burrows from Pleistocene and Holocene paleosols are the only trace fossils that have been specifically attributed to the burrowing of cicada nymphs (O'Geen et al., 2002; Gregory et al., 2004; Jacobs and Mason, 2004). Naktodemasis bowni is most similar in its morphology, inferred ethology, and depositional and paleoecological setting to traces produced by cicada nymphs in this study (Smith et al., 2008). First described from floodplain paleosols of the Paleogene Willwood Formation in the Bighorn Basin, Wyoming (Bown and Kraus, 1983), burrows similar in morphology to $N$. bowni have since been reported from continental deposits dating back to the late Paleozoic (Counts and Hasiotis, 2007). Meniscate burrows assigned to $N$. bowni are composed of a series of distinct packets, commonly crosscutting one another, that contain thin, discontinuous meniscate fill (Figs. 8C-D). These meniscate burrows can thus be used as proxies in the fossil record for the likely presence of cicada nymphs and other backfilling hemipterans with similar burrowing behaviors (Willis and Roth, 1962; Smith et al., 2008), such as burrower bugs (Hemiptera: Cydnidae), though with potentially recognizable differences in trace morphology. In addition, such meniscate trace fossils in paleosols and alluvial deposits indicate that burrowing behaviors and terrestrial, subterranean lifestyles date to the earliest body fossil occurrences of hemipterans in the Permian.

Cicada emergence burrows (e.g., White et al., 1979; Humphreys, 1989; Luken and Kalisz, 1989) would be most similar to the trace fossil Macanopsis astreptum or Cylindricum isp., depending on whether an enlarged feeding cell is preserved at the burrow terminus. Both ichnofossils are predominately vertical, smooth-walled burrows with circular cross sections; however, Macanopsis terminates in a roughly spherical chamber larger in diameter than the burrow shaft (Bown and Kraus, 1983), and Cylindricum burrows are test-tube shaped with gently rounded terminations (Linck, 1949). Such vertical burrows are common in continental deposits and in association with backfilled burrows. In addition, emergence burrows could potentially be preserved in high densities similar to Cylindricum, particularly in the case of periodical cicada broods, which exit the soil simultaneously by the millions (e.g., Williams and Simon, 1995). Passively filled vertical burrows in some paleosols may have been constructed by emerging fifth instars (e.g., Retallack, 1997), though diagnostic characteristics of such traces are not well established and similar burrows are produced by a wide variety of organisms in continental deposits (e.g., Ratcliffe and Fagerstrom, 1980; Bown and Kraus, 1983; Hasiotis, 2002).

The emergence burrows of 13- and 17-year periodical cicadas, if recognized as such in the geologic record, could be used potentially as in situ geochronometers under the right depositional conditions. Alluvial floodplain and loess environments in which sedimentation rates are steady but of low volume are most likely to preserve individual cicada emergence events. Vertical aggradation rates vary widely on modern floodplains and range from $0 \mathrm{~mm} \cdot \mathrm{yr}^{-1}$ to $760 \mathrm{~mm} \cdot \mathrm{yr}^{-1}$ (e.g., Rumsby, 2000) but is most commonly $<10 \mathrm{~mm} \cdot \mathrm{yr}^{-1}$. For individual emergence events in the alluvial record to be observable, sediment aggradation between emergences would have to be of such thickness that succeeding generations of emergence burrows did not overlap, but not so thick and rapid that burrowing cicadas were permanently buried. For example, given the 70-360 mm range of 17-year cicada emergence burrow lengths reported by Luken and Kalisz (1989), vertical aggradation would have to exceed $\sim 21 \mathrm{~mm} \cdot \mathrm{yr}^{-1}$ between emergences to preserve distinct and nonoverlapping emergence events.

It should be noted that the depth of the experimental enclosures likely influenced the ability of Cicadetta calliope nymphs to produce deep burrows and long emergence tunnels but not their ability to produce horizontal burrows or feeding cells. Future neoichnologic studies of soil organisms may be improved by using larger enclosures when possible, which would allow the organisms to burrow to depths similar to those observed in their natural habitats. In addition, varying the grain size, mineralogy, organic content, and moisture conditions of experimental media will likely reveal differences in burrowing behaviors, traces produced, and survivability of the trace makers (e.g., Hembree and Hasiotis, 2006). This study should be viewed as a first step toward addressing the disparity between neoichnologic studies of marine invertebrates and their terrestrial and aquatic counterparts in continental settings.

\section{CONCLUSIONS}

Invertebrate trace fossils from continental deposits, especially paleosols, are often interpreted as the burrows, tracks, and trails of insects, though clear affinities with specific taxa in many instances are doubtful. 

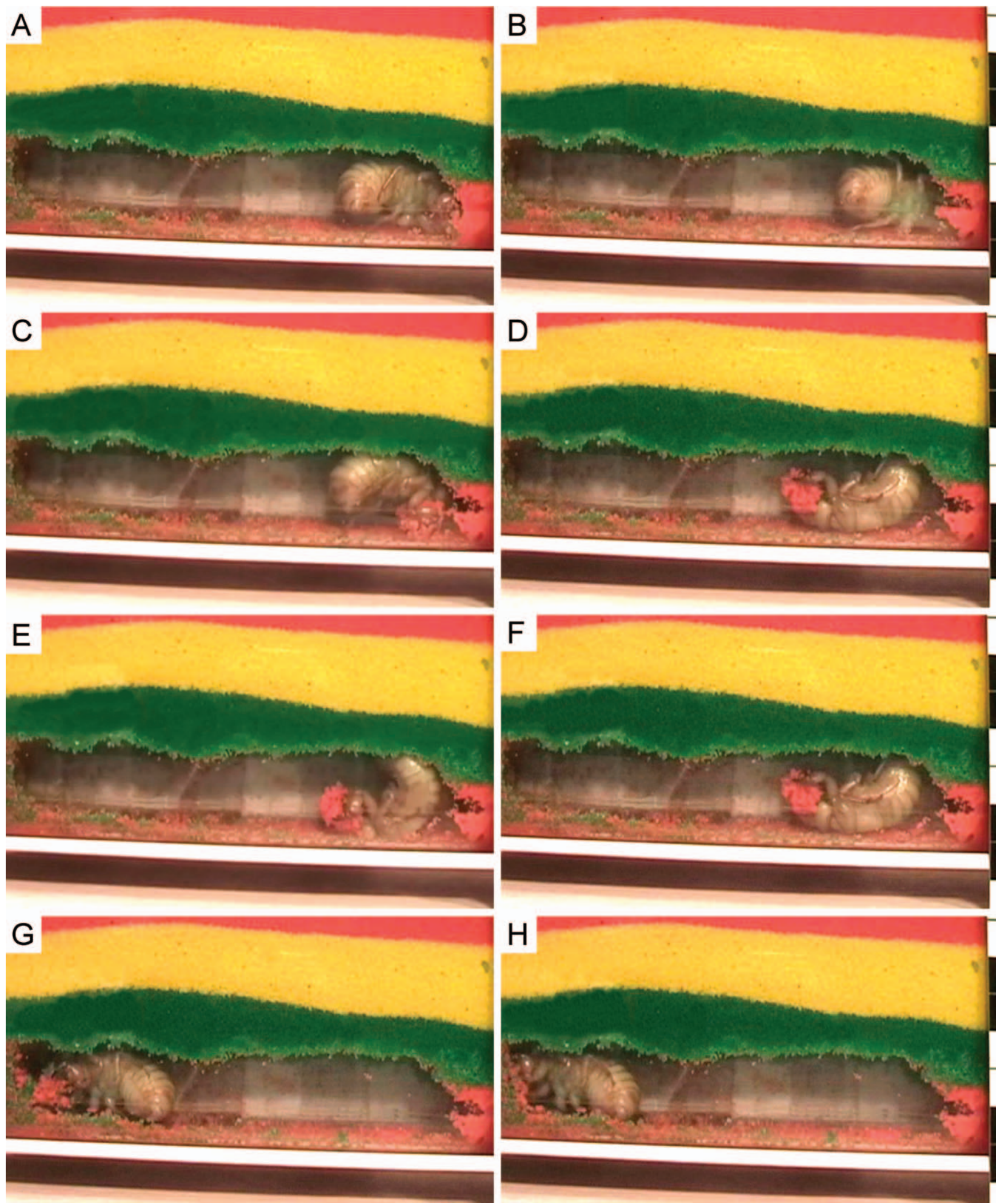

FIGURE 6-Screen captures of video showing Cicadetta calliope nymph burrowing behaviors: A) Nymph thrusts forelimbs into sediment, drawing back clumps with each thrust. B) Forelimbs scoop sediment toward body. C) Sediment ball is compacted and held against the head by the forelimbs. D-F) Nymph rotates $180^{\circ}$ forward while holding the sediment ball. G) The sediment ball is pushed against the cell wall with forelimbs. H) The sediment is kneaded into a thin layer against the aft cell wall, thus backfilling the cell. See Supplementary Data ${ }^{1}$ for video. 

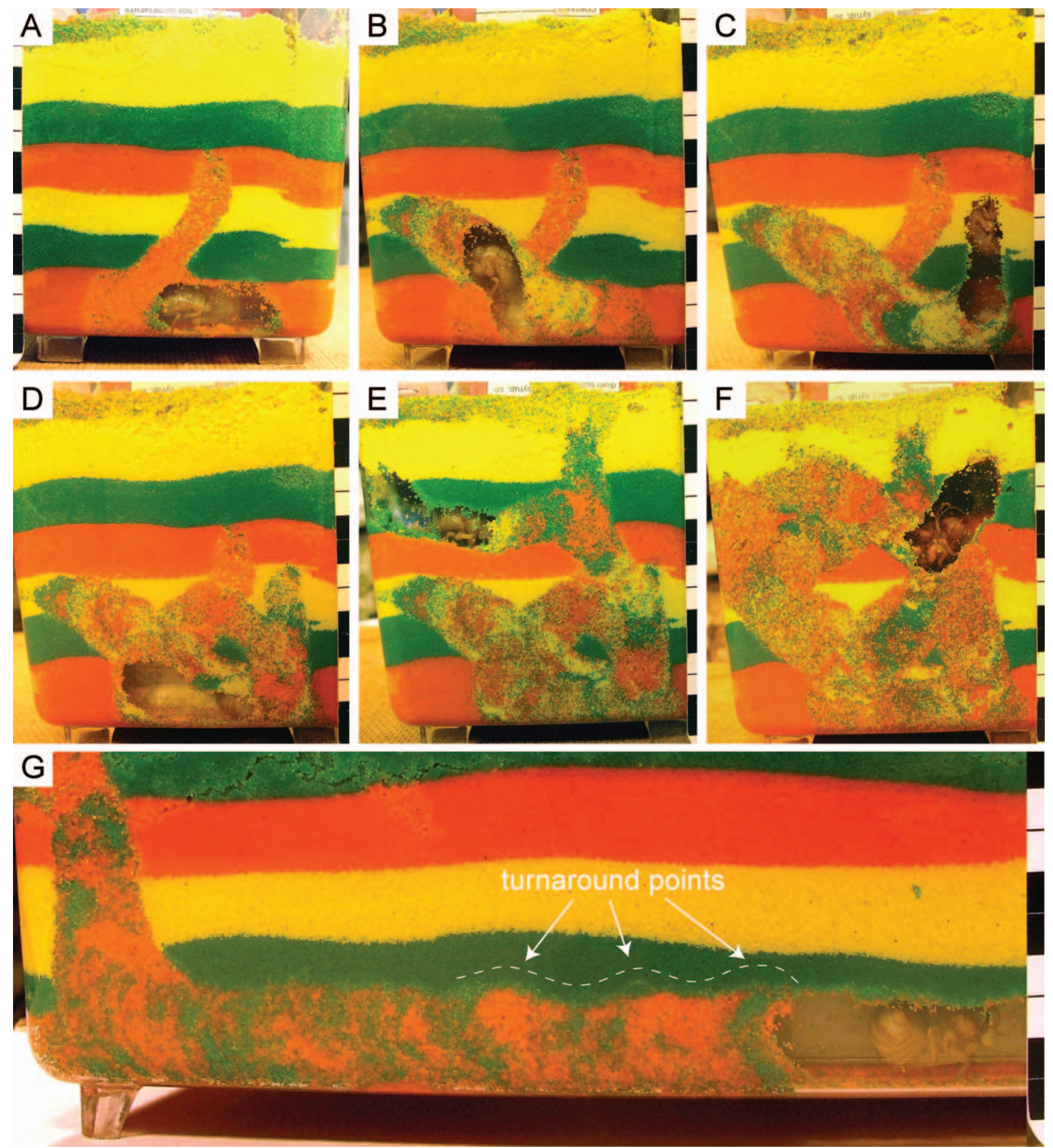

FIGURE 7-Experimental enclosure $>15$ days of burrowing by Cicadetta calliope nymph (A-F). Enlargements along the length of the burrow correspond to turnaround points for the backfilling cicada $(\mathrm{G})$.

Neoichnological experiments with extant continental organisms are thus paramount because the resulting traces or elements of the traces can be attributed directly to a specific trace maker or to groups of trace makers with similar bauplans, behaviors, life cycles, and environmental requirements (e.g., Hasiotis et al., 1993; Hembree and Hasiotis, 2006, 2007). The interpretive power of continental ichnology is therefore greatly increased, even when the exact trace maker is unknown.

This research has shown that backfilled burrows are not all produced by sediment ingestion and excretion in aquatic or saturated sediment conditions. The morphology of meniscate traces produced by cicada nymphs and perhaps other similarly adapted burrowing hemipterans are distinct and attributable to specific behaviors and portions of the life cycle of the organism. Such traces can be used as proxy evidence of biodiversity in ancient soils, since the body fossils of insects and other soil arthropods are rarely preserved in situ.

The presence of meniscate trace fossils attributable to insect larvae is 

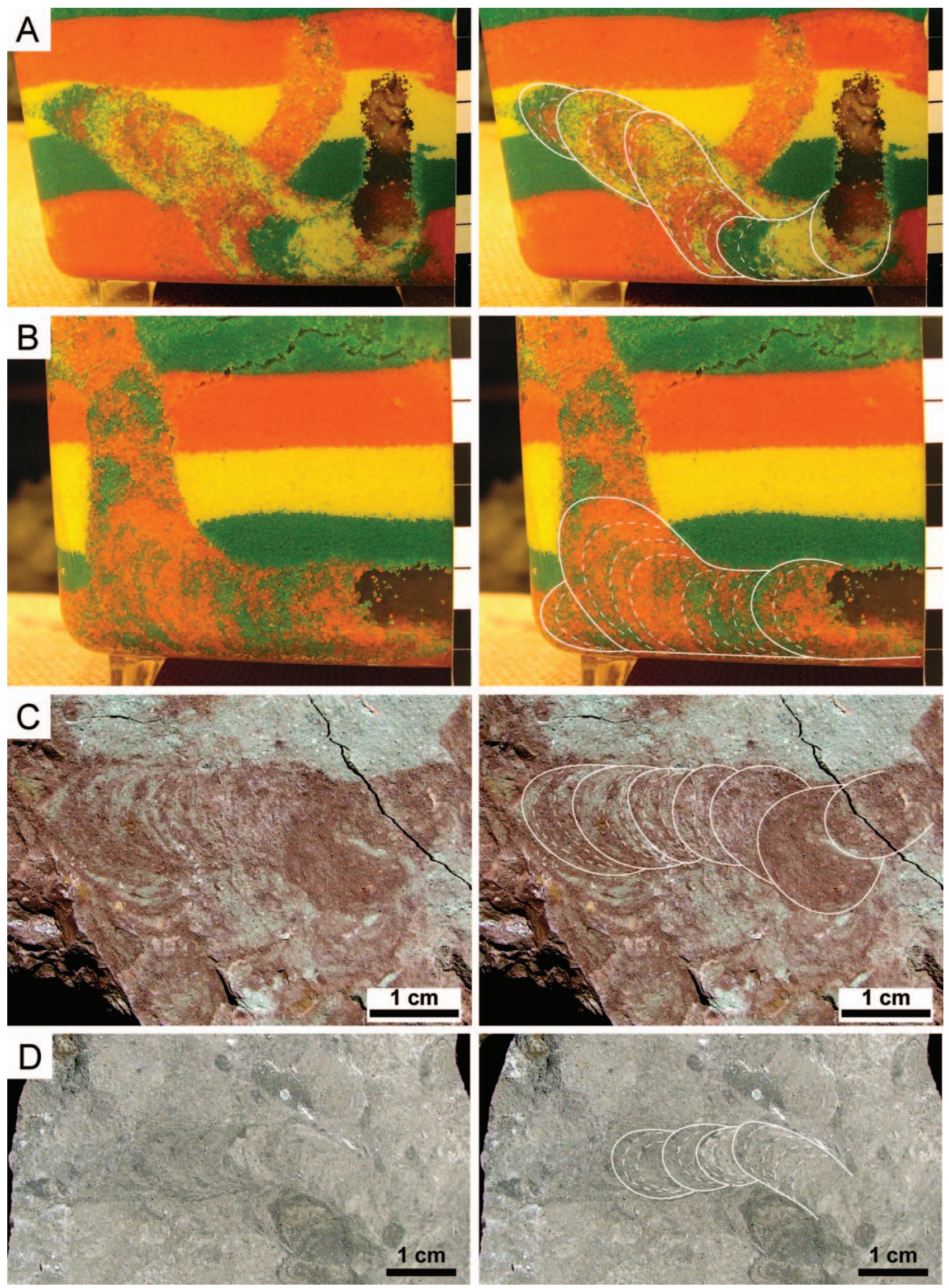

FIGURE 8-Comparison of Cicadetta calliope nymph backfilled burrows (A-B) with the trace fossil Naktodemasis bowni (C-D). N. bowni specimens from a well-developed, well-drained paleosol (C) and a clay-rich sandstone deposited during an avulsion (D) in the Paleogene Willwood Formation, Bighorn Basin, Wyoming. 
itself an indicator of ancient pedogenesis, as burrowing insects are a major faunal component in modern soils and are primary agents of pedoturbation (Thorp, 1949; Wallwork, 1970; Hole, 1981; Hasiotis, 2002, 2007). Trace fossils similar to those produced by Cicadetta calliope can be used as indicators of subaerial exposure and improved drainage conditions in continental deposits, as modern cicadas are limited to welldrained soils with conditions typical of the vadose zone in the groundwater profile. Information about the degree of ancient soil moisture regimes is important for understanding past climate conditions and reconstructing continental paleolandscapes. Nymph burrows also suggest the presence of plant roots, another indicator of soil formation. Meniscate trace fossils, such as Naktodemasis bowni, are very similar morphologically to the burrows of modern cicada nymphs. This strong resemblance suggests that $N$. bowni trace makers and extant cicada nymphs had similar body plans, burrowing methods, and habitat requirements. Trace fossils with similar morphologies to the modern nymph traces may be used to extend the geographic and stratigraphic range of these organisms in the fossil record.

\section{ACKNOWLEDGMENTS}

This research was funded by National Science Foundation Earth Sciences grant EAR-0229300 to STH. JJS also thanks the University of Kansas Biodiversity Research Center for supporting this research. We thank Allen Sanborn, William Cook, Edith L. Taylor, and the editorial staff of PALAIOS for their thoughtful and constructive reviews that greatly improved the clarity of this manuscript.

\section{REFERENCES}

Atkinson, R.J.A., and TAYLOR, A.C., 1991, Burrows and burrowing behaviour of fish, in Meadows, P.S., and Meadows, A., eds., The Environmental Impact of Burrowing Animals and Animal Burrows: Symposia of the Zoological Society of London, no. 63, Clarendon Press, Oxford, UK, p. 133-155.

Beamer, R.H., 1928, Studies on the biology of Kansas Cicadidae: University of Kansas Science Bulletin, v. 18, p. 155-263.

Bown, T.M., 1982, Ichnofossils and rhizoliths of the nearshore fluvial Jebel Qatrani Formation (Oligocene), Fayum Province, Egypt: Palaeogeography, Palaeoclimatology, Palaeoecology, v. 40, p. 255-309.

Bown, T.M., and Kraus, M.J., 1983, Ichnofossils of the alluvial Willwood Formation (lower Eocene), Bighorn Basin, northwest Wyoming, U. S. A.: Palaeogeography, Palaeoclimatology, Palaeoecology, v. 43, p. 95-128.

Brady, N.C., and Weil, R.R., 2002, The Nature and Properties of Soils: Prentice Hall, Englewood Cliffs, New Jersey, 960 p.

Bromley, R.G., 1996, Trace Fossils: Biology, Taphonomy and Applications: Chapman \& Hall, London, $361 \mathrm{p}$

Bromley, R.G., and AsgaArd, U., 1975, Sediment structures produced by a spatangoid echinoid: A problem of preservation: Bulletin of the Geological Society of Denmark, v. 24, p. 261-281.

Bromley, R.G., Buatois, L.A., Genise, J.F., Labandeira, C.C., Mángano, M.G., MelCHOR, R.N., Schlirf, M., and Uchman, A., 2007, Comments on the paper "Reconnaissance of Upper Jurassic Morrison Formation ichnofossils, Rocky Mountain region, USA: Paleoenvironmental, stratigraphic, and paleoclimatic significance of terrestrial and freshwater ichnocoenoses" by Stephen T. Hasiotis: Sedimentary Geology, v. 200, p. 141-150.

Buatois, L.A., and Mángano, M.G., 2004, Animal-substrate interactions in freshwater environments: Applications of ichnology in facies and sequence stratigraphic analysis of fluvio-lacustrine successions, in McIlroy, D., ed., The Application of Ichnology to Palaeoenvironmental and Stratigraphic Analysis: Geological Society of London, Special Publications, v. 228, p. 311-333.

Buatois, L.A., and Mángano, M.G., 2007, Invertebrate ichnology of continenta freshwater environments, in Miller, W., III, ed., Trace Fossils: Concepts, Problems, Prospects: Elsevier, Amsterdam, p. 285-323.

Buatois, L.A., Mángano, M.G., Genise, J.F., and Taylor, T.N., 1998, The ichnologic record of the continental invertebrate invasion: Evolutionary trends in environmental expansion, ecospace utilization, and behavioral complexity: PALAIOS, v. 13 , p. $217-240$.

Clark, G.R., and Ratcliffe, B.C., 1989, Observations on the tunnel morphology of Heterocerus brunneus Melsheimer (Coleoptera: Heteroceridae) and its paleoecological significance: Journal of Paleontology, v. 63, p. 228-232.
CounTs, J.W., and Hasiotis, S.T., 2007, Neoichnology of scarab beetle larvae: Modern analogues for backfilled trace fossils: Geological Society of America Abstracts with Programs, v. 39, p. 54

Cox, R.T., and Carlton, C.E., 1988, Paleoclimatic influences in the evolution of periodical cicadas (Insecta: Homoptera: Cicadidae: Magicicada spp.): American Midland Naturalist, v. 120, p. 183-193.

D'Alessandro, A., and Bromley, R.G., 1987, Meniscate trace fossils and the Muensteria-Taenidium problem: Palaeontology, v. 30, p. 743-763.

DAVIS, W.T., 1920, North American cicadas belonging to the genera Platypedia and Melampsalta: Journal of the New York Entomological Society, v. 28, p. 95-145.

Dietrich, C.H., 2003, Auchenorrhyncha (Cicadas, Spittlebugs, Leafhoppers, Treehoppers, and Planthoppers), in Resh, V.H., and Cardé, R.T., eds., Encyclopedia of Insects: Academic Press, San Diego, p. 66-75.

Dybas, H.S., and Davis, D.D., 1962, A population census of seventeen-year periodical cicadas (Homoptera: Cicadidae: Magicicada): Ecology, v. 43, p. 432-444.

Ekdale, A.A., and Berger, W.H., 1978, Deep-sea ichnofacies: Modern organism traces on land and in pelagic carbonates of the western equatorial Pacific: Palaeogeography Palaeoclimatology Palaeoecology, v. 23, p. 263-278.

FREY, R.W., 1968, The Lebensspuren of some common marine invertebrates near Beaufort, North Carolina: Pt. 1, Pelecypod burrows: Journal of Paleontology, v. 42 , p. $570-574$.

FreY, R.W., 1970, The Lebensspuren of some common marine invertebrates near Beaufort, North Carolina: Pt. 2, Anemone burrows: Journal of Paleontology, v. 44, p. 308-311.

Frey, R.W., Curran, H.A., and Pemberton, S.G., 1984, Tracemaking activities of crabs and their environmental significance: The ichnogenus Psilonichnus: Journal of Paleontology, v. 58 , p. 333-350.

Frey, R.W., Howard, J.D., and Pryor, W.A., 1978, Ophiomorpha: Its morphologic, taxonomic, and environmental significance: Palaeogeography, Palaeoclimatology, Palaeoecology, v. 23, p. 199-229.

Genise, J.F., Bellosi, E.S., and GonZÁLEZ, M.G., 2004, An approach to the description and interpretation of ichnofabrics in paleosols, in McIlroy, D., ed., The Application of Ichnology to Palaeoenvironmental and Stratigraphic Analysis: Geological Society of London, Special Publications, v. 228, p. 355-382.

GENISE, J.F., and Bown, T.M., 1994, New trace fossils of termites (Insecta: Isoptera) from the Late Eocene-early Miocene of Egypt, and the reconstruction of ancient isopteran behavior: Ichnos, v. 3, p. 155-183.

Gingras, M.K., MacEachern, J.A., and Pickerill, R.K., 2004, Modern perspectives on the Teredolites ichnofacies: Observations from Willapa Bay, Washington: PALAIOS, v. 19, p. 79-88.

Gingras, M.K., Pickerill, R., and Pemberton, S.G., 2002, Resin cast of modern burrows provides analogs for composite trace fossils: PALAIOS, v. 17, p. 206211.

Gregory, M.R., Martin, A.J., and Campbell, K.A., 2004, Compound trace fossils formed by plant and animal interactions: Quaternary of northern New Zealand and Sapelo Island, Georgia (USA): Fossils and Strata, v. 51, p. 88-105.

Hasiotis, S.T., 2002, Continental Trace Fossils: SEPM Short Course Notes, no. 51, Tulsa, Oklahoma, 134 p.

Hasiotis, S.T., 2004, Reconnaissance of Upper Jurassic Morrison Formation ichnofossils, Rocky Mountain Region, USA: Paleoenvironmental, stratigraphic, and paleoclimatic significance of terrestrial and freshwater ichnocoenoses: Sedimentary Geology, v. 167 , p. $177-268$

Hasiotis, S.T., 2007, Continental ichnology: Fundamental processes and controls on trace fossil distribution, in Miller, W., III, ed., Trace Fossils: Concepts, Problems, Prospects: Elsevier, Amsterdam, p. 262-278.

Hasiotis, S.T., and Bown, T.M., 1992, Invertebrate ichnofossils: The backbone of continental ichnology, in Maples, C.G., and West, R.R., eds., Trace Fossils: Paleontological Society Short Course, no. 5, Knoxville, Tennessee, p. 64-104.

Hasiotis, S.T., and Demкo, T.M., 1996, Terrestrial and freshwater trace fossils, Upper Jurassic Morrison Formation, Colorado Plateau, in Morales, M., ed., The Continental Jurassic: Museum of Northern Arizona Bulletin, Flagstaff, v. 60, p. 355370 .

Hasiotis, S.T., and Dubiel, R.F., 1994, Ichnofossil tiering in Triassic alluvial paleosols: Implications for Pangean continental rocks and paleoclimate, in Beauchamp, B., Embry, A.F., and Glass, D., eds., Pangea: Global Environments and Resources: Canadian Society of Petroleum Geologists Memoirs, no. 17, p. 311-317.

Hasiotis, S.T., and Mitchell, C.E., 1993, A comparison of crayfish burrow morphologies: Triassic and Holocene fossil, paleo- and neo-ichnological evidence, and the identification of their burrowing signatures: Ichnos, v. 2, p. 291-314.

Hasiotis, S.T., Mitchell, C.E., and Dubiel, R.F., 1993, Application of morphologic burrow interpretations to discern continental burrow architectures: Lungfish or crayfish?: Ichnos, v. 2, p. 315-333.

Heath, J.E., 1968, Thermal synchronization of emergence in periodical "17-year" cicadas (Homoptera, Cicadidae, Magicicada): American Midland Naturalist, v. 80, p. 440-448. 
Hembree, D.I., and Hasiotis, S.T., 2006, The identification and interpretation of reptile ichnofossils in paleosols through modern studies: Journal of Sedimentary Research, v. 76, p. 575-588

Hembree, D.I., and Hasiotis, S.T., 2007, Biogenic structures produced by sand-swimming snakes: A modern analog for interpreting continental ichnofossils: Journal of Sedimentary Research, v. 77, p. 389-397.

Hole, F.D., 1981, Effects of animals on soil: Geoderma, v. 25, p. 75-112.

Hugie, V.K., and Passey, H.B., 1963, Cicadas and their effect upon soil genesis in certain soil in southern Idaho, northern Utah, and northeastern Nevada: Soil Science Society of America Proceedings, v. 27, p. 78-82.

HumphreYs, G.S., 1989, Earthen structures built by nymphs of the cicada Cyclochila austalasiae (Donovan) (Homoptera: Cicadidae): Australian Entomological Magazine, v. 16, p. 99-108

Jacobs, P.M., and Mason, J.A., 2004, Paleopedology of soils in thick Holocene loess, Nebraska, USA: Revista Mexicana de Ciencias Geológicas, v. 21, p. 54-70.

Kanazawa, K., 1992, Adaptation of test shape for burrowing and locomotion in spatangoid echinoids: Palaeontology, v. 35, p. 733-750.

Keighley, D.G., and Pickerill, R., 1994, The ichnogenus Beaconites and its distinction from Ancorichnus and Taenidium: Palaeontology, v. 37, p. 305-337.

Lefebvre, F., Nel, A., Papier, F., Grauvogel-Stamm, L., and Gall, J.-C., 1998, The first "cicada-like Homoptera" from the Triassic of the Vosges, France: Palaeontology, v. 41, p. 1195-1200.

Linck, O., 1949, Lebens-Spuren aus dem Schilfsandstein (Mittlerer Keuper, km2) Nordwest-Württembergs und ihre Bedeutung für die Bildungsgeschichte der Stufe: Jahreshefte des Vereins für Vaterländische Naturkunde im Württemberg, v. 97101, p. $1-100$.

Lloyd, M., and Dybas, H.S., 1966, The periodical cicada problem: Pt. I. Population ecology: Evolution, v. 20, p. 133-149.

Luken, J.O., and KaLisz, P.J., 1989, Soil disturbance by the emergence of periodical cicadas: Soil Science Society of America Journal, v. 53, p. 310-313.

Metcalf, Z.P., 1963, General Catalogue of the Homoptera, Fascicle VIII: Cicadoidea: Pt. 1. Cicadidae: Section II. Gaeninae and Cicadinae: North Carolina State College Contributions, no. 1502, p. 587-919.

Moulds, M.S., 2003, Cicadas, in Resh, V.H., and Cardé, R.T., eds., Encyclopedia of Insects: Academic Press, San Diego, p. 186-188.

Moulds, M.S., 2005, An appraisal of the higher classification of cicadas (Hemiptera: Cicadoidea) with special reference to the Australian fauna: Records of the Australian Museum, v. 57, p. 375-446.

O'GeEn, A.T., and BusacCA, A.J., 2001, Faunal burrows as indicators of paleo-vegetation in eastern Washington, USA: Palaeogeography, Palaeoclimatology, Palaeoecology, v. 169 , p. $23-37$.

O'Geen, A.T., McDaniel, P.A., and Busacca, A.J., 2002, Cicada burrows as indicators of paleosols in the inland Pacific Northwest: Soil Science Society of America Journal, v. 66, p. 1584-1586.

Pemberton, S.G., and Frey, R.W., 1985, The Glossifungites ichnofacies: Modern examples from the Georgia coast, U.S.A.: SEPM (Society for Sedimentary Geology) Special Publications, v. 35, p. 273-259.

Pemberton, S.G., MacEachern, J.A., and Frey, R.W., 1992, Trace fossil facies models: environmental and allostratigraphic significance, in Walker, R.G. and James, N.P., eds., Facies Models: Response to Sea Level Change: Geological Association of Canada, St. John's, Newfoundland, p. 47-72

Rasnitsyn, A.P., and Quicke, D.L.J., 2002, History of Insects: Kluwer Academic Publishers, Dordrecht, 517 p.

RatclifFe, B.C., and Fagerstrom, J.A., 1980, Invertebrate Lebensspuren of Holocene floodplains: Their morphology, origin and paleoecological significance: Journal of Paleontology, v. 54, p. 614-630.

Retallack, G.J., 1997, Palaeosols in the upper Narrabeen Group of New South
Wales as evidence of early Triassic palaeoenvironments without exact modern analogues: Australian Journal of Earth Sciences, v. 44, p. 185-201.

Rumsby, B., 2000, Vertical accretion rates in fluvial systems: A comparison of volumetric and depth-based estimates: Earth Surface Processes and Landforms, v. 25, p. 617-631.

SAVRDA, C.E., 1995, Ichnologic applications in paleoceanographic, paleoclimatic, and sea-level studies: PALAIOS, v. 10, p. 565-577.

Savrda, C.E., Blanton-Hooks, A.D., Collier, J.W., Drake, R.A., Graves, R.L. Hall, A.G., Nelson, A.I., Slone, J.C., Williams, D.D., and Wood, H.A., 2000 , Taenidium and associated ichnofossils in fluvial deposits, Cretaceous Tuscaloosa Formation, eastern Alabama, southeastern U.S.A.: Ichnos, v. 7, p. 227-242.

Schwertmann, U., 1993, Relations between iron oxides, soil color, and soil formation: Journal of Soil Science, v. 31, p. 51-69.

SeIlacher, A., 1978, Use of trace fossils for recognizing depositional environments, in Basan, P.B., ed., Trace Fossil Concepts: Society of Economic Paleontologists and Mineralogists, Short Course, no. 5, p. 167-181.

Shcherbakov, D.Y., 1984, Systematics and phylogeny of Permian Cicadomorpha (Cimicada and Cicadina): Paleontological Journal, v. 18, p. 87-97.

Simon, C., Karban, R., and Lloyd, M., 1981, Patchiness, density, and aggregative behavior in sympatric allochronic populations of 17-year cicadas: Ecology, v. 62, p. $1525-1535$.

Smith, J.J., Hasiotis, S.T., Woody, D.T., and Kraus, M.J., 2008, Naktodemasis bowni: New ichnogenus and ichnospecies for adhesive meniscate burrows (AMB), and paleoenvironmental implications, Paleogene Willwood Formation, Bighorn Basin, Wyoming: Journal of Paleontology, v. 82, p. 267-278.

Smith, R.C., Kelly, E.G., Dean, G.A., Bryson, H.R., and Parker, R.L., 2000, Insects in Kansas: 3rd ed., rev. White, S.C., and Salsbury, G.A., Kansas Department of Agriculture, Manhattan, $521 \mathrm{p}$.

Strandine, E.J., 1940, A quantitative study of the periodical cicada with respect to soil of three forests: American Midland Naturalist, v. 24, p. 177-183.

Thackray, G.D., 1994, Fossil nest of sweat bees (Halictinae) from a Miocene paleosol, Rusinga Island, western Kenya: Journal of Paleontology, v. 68, p. 795800

Thorp, J., 1949, Effects of certain animals that live in soil: Scientific Monthly, v. 68, p. $180-191$.

Toots, H., 1967, Invertebrate burrows in the non-marine Miocene of Wyoming: Contributions to Geology, v. 6, p. 93-96.

Tschinkel, W.R., 2003, Subterranean ant nests: Trace fossils past and future?: Palaeogeography, Palaeoclimatology, Palaeoecology, v. 192, p. 321-333.

VEPRASKAS, M.J., 1999, Redoximorphic features for identifying aquic conditions: North Carolina Agricultural Research Service, Technical Bulletin, no. 301, 33 p.

WALKER, F., 1850, List of the specimens of Homopterous insects in the collection of the British Museum, v. 1, London, 260 p.

Wallwork, J.A., 1970, Ecology of Soil Animals: McGraw Hill, London, 238 p.

Whiles, M.R., Callaham, M.A., Meyer, C.K., Brock, B.L., and Charlton, R.E., 2001, Emergence of periodical cicadas (Magicicada cassini) from a Kansas riparian forest: Densities, biomass and nitrogen flux: American Midland Naturalist, v. 145 , p. $176-187$.

White, J., Lloyd, M., and Zar, J.H., 1979, Faulty eclosion in crowded suburban periodical cicadas: Populations out of control: Ecology, v. 60, p. 305-315.

White, J., and Strehl, C., 1978, Xylem feeding by periodical cicada nymphs on tree roots: Ecological Entomology, v. 3, p. 323-327.

Williams, K.S., and Simon, C., 1995, The ecology, behavior, and evolution of periodical cicadas: Annual Review of Entomology, v. 40, p. 269-295

Willis, E.R., and Rотн, L.M., 1962, Soil and moisture relations of Scaptocoris divergens Froeschner (Hemiptera: Cydnidae): Annals of the Entomological Society of America, v. 55, p. 21-32.

ACCEPTED FEBRUARY 26, 2008 